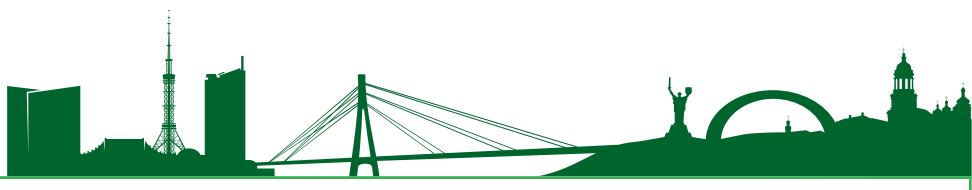

УДК 624.012.25

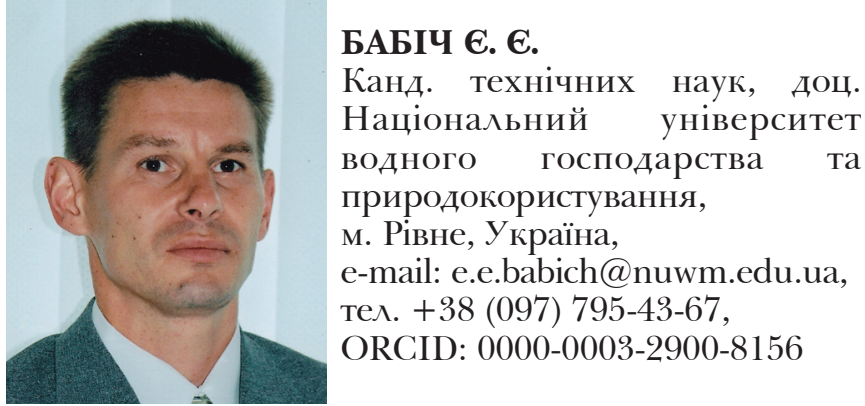

\title{
ПРАКТИЧНИЙ МЕТОД РОЗРАХУНКУ СТИСНУТО-ЗІГНУТИХ ЗАЛІЗОБЕТОННИХ ЕАЕМЕНТІВ ЗА ГРАНИЧНИМИ СТАНАМИ ДРУГОЇ ГРУПИ
}

\begin{abstract}
АНОТАЦІЯ
Стиснуто-зігнуті елементи, що стиснуті поздовжньою силою і сприймають певні поперечні навантаження, широко використовуються в будівельній практиці (ригелі і колони рам, елементи опор мостів, верхні пояси ферм із позавузловим навантаженням тощо). В чинних нормативних документах стиснуто-зігнуті елементи практично не розглядаються, але є розробки, в яких вирішуються питання несучої здатності таких елементів на основі деформаційної моделі. У зв’язку з цим є доцільним і важливим розробити метод розрахунку стиснутозігнутих елементів за граничними станами другої групи.
\end{abstract}

Відсутність посібників із проектування залізобетонних конструкцій є суттєвою перепоною в успішному використанні нових нормативних документів у проектній практиці.

У статті висвітлено розроблений практичний метод розрахунку стиснуто-зігнутих залізобетонних елементів за шириною розкриття тріщин та за деформаціями, так як в чинних нормативних документах представлені тільки основні положення та правила проектування конструкцій за сучасною деформаційною моделлю стосовно згинальних та позацентрово стиснутих елементів. Наведено математично удосконалені рівняння рівноваги нормальних перерізів, в яких застосовані коефіцієнти повноти епюри напружень у стиснутому бетоні та відносних згинальних моментів, що діють у нормальному перерізі. Значення коефіцієнтів залежать тільки від класу бетону з урахуванням його механічного стану, а тому для них складена таблиця. Розв'язання рівнянь рівноваги дає можливість знаходити параметри, що входять у розрахункові формули для визначення ширини розкриття тріщин та прогинів, а саме: деформації в бетоні та арматурі, напруження в арматурі та кривизну елемента за будь-якого рівня навантаження. Запропонований метод дає можливість спрости- ти розрахунки стиснуто-зігнутих залізобетонних елементів за граничними станами другої групи та сприятиме використанню в проектній практиці деформаційної моделі в повному обсязі.

КАЮЧОВІ СЛОВА: стиснуто-зігнуті залізобетонні елементи, тріщини, прогини, розрахунок.

THE PRACTICAL METHOD FOR COMPRESSEDBENT REINFORGED CONGRETE ELEMENTS CALCULATION ACCORDING TO THE SECOND GROUP LIMIT STATES

BABICH Y.Y. PhD, Ass. Prof., National University of Water Management and Nature Resources Use, Rivne, Ukraine,

e-mail: e.e.babich@nuwm.edu.ua, тел.. +38 (097) 795-43-67,

ORCID: 0000-0003-2900-8156

\section{ABSTRACT}

The compression-bent elements, compressed by longitudinal force and perceive certain transverse loads, are widely used in building (crossbars and columns of frames, elements of bridges, upper belts of ferms with an out-of-nosed load, etc.). In current normative documents, compressed-bent elements are practically not considered, but there are developments which solve the bearing capacity of such elements based on the deformation model. In this regard, it is expedient and important to develop a method for calculating compressed-bent elements by the serviceability limit state. The lack of manuals for the design of reinforced concrete constructions is a significant barrier to the successful use of new normative documents in project practice.

This article describes the developed practical method for calculating compressed-bent concrete elements for the width of crack opening and deformation, as in the current normative documents only the main provisions and rules for designing constructions according to the modern deformation model in relation to bending and 


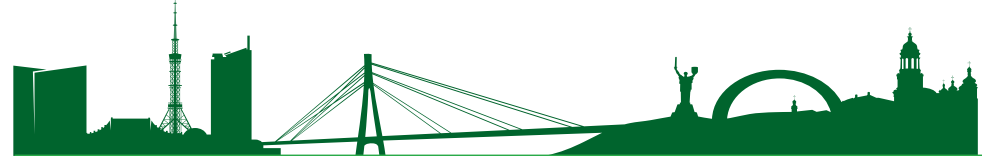

non-centered compressed elements are given. The mathematically improved equilibrium equations of normal sections are presented, in which the coefficients of the completeness of the stress diagram in compressed concrete and the relative bending moments acting in the normal section are applied. The values of the coefficients depend only on the class of concrete, taking into account its mechanical condition, and therefore for them a table is drawn up.

The solution of the equations of equilibrium makes it possible to find the parameters that are included in the calculation formulas for determining the width of the opening of cracks and deflections, namely: deformation in concrete and reinforcement, stress in the reinforcement and the curvature of the element at any load level. The proposed method makes it possible to simplify calculations of reinforced concrete compressed-bent elements by the serviceability limit state and will facilitate the use in the design practice of the deformation model in full.

KEY WORDS: compressed-bent, reinforced concrete elements, cracks, bends, calculation.

ПОСТАНОВКА МЕТИ ДОСАІДЖЕНЬ ТА ЇЇ ЗВ'ЯЗОК ІЗ ПРАКТИЧНИМИ ЗАВДАННЯМИ

Стиснуто-зігнуті залізобетонні стержневі елементи, що одночасно сприймають поздовжні і поперечні навантаження, є найбільш поширеними в складі будівель та споруд (рис. 1). Позацентрово стиснуті залізобетонні елементи можна розглядати як окремий випадок стиснуто-зігнутих, у яких ексцентриситет прикладання поздовжньої сили по довжині практично постійний, а поперечне навантаження відсутнє. До стиснуто-зігнутих залізобетонних конструкцій відносять колони одноповерхових виробничих будівель, окремі колони багатоповерхових будівель та різноманітних споруд, елементи підпірних стін, стояки транспортних естакад, тощо.

B основу сучасних норм проектування залізобетонних конструкцій прийнята теоретично і експериментально обгрунтована нелінійна деформаційна методика [4], що передбачає врахування не зусиль, а деформацій матеріалів у перерізах елементів. В основу деформаційної методики покладено діаграми стану (деформування) бетону і арматури, що встановлюють зв'язок між нормальними напруженнями та відносними поздовжніми деформаціями у разі осьового стиску чи розтягу $[1,2]$. У нормах проектування залізобетонних конструкцій [3] регламентовано основні вимоги щодо забезпечення несучої

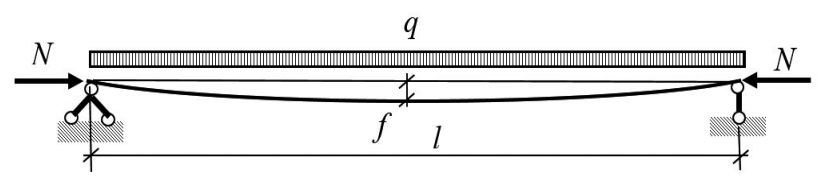

Рис. 1. Розрахункова схема стиснуто-зігнутого елемента здатності, придатності до експлуатації, надійності та здатності усіх конструкцій зберігати необхідні експлуатаційні властивості протягом усього терміну служби незалежно від характеру їхнього напружено-деформованого стану.

у правилах проектування залізобетонних конструкцій [4] встановлено передумови розрахунку бетонних і залізобетонних конструкцій за граничними станами першої і другої груп. Більш докладно розглянуто визначення напруженодеформованого стану елементів при позацентровому стиску та згині, а стиснуто-зігнуті елементи не згадуються взагалі. Крім цього, в [4] не наводиться докладно метод розрахунку залізобетонних елементів за граничними станами другої групи. Такі обставини спричиняють певні труднощі в розрахунках конструкцій і стримують успішне використання деформаційної методики в проектній практиці. Таким чином, наразі практично відсутнє методичне забезпечення успішного використання в проектній практиці деформаційної моделі залізобетону.

Метою досліджень є визначення умов рівноваги нормальних перерізів стиснуто-зігнутих елементів за рахунок математичних перетворень, спростити розрахункові формули та розробити докладний метод визначення прогинів та ширини розкриття тріщин, що буде мати безпосередній зв'язок із деформаційною модемлю при вирішенні практичних завдань проектування залізобетонних конструкцій.

\section{АНАЛІЗ ОСТАННІХ ПУБАІКАЦІЙ ТА НЕВИРIШЕНI РАНIUЕ ПИТАННЯ}

Теоретичних та експериментальних досліджень роботи стиснуто-зігнутих залізобетонних елементів виконано обмежену кількість. Основні положення розрахунку стиснуто-зігнутих елементів висвітлено в [5], де наведено їхні основні характеристики, відмінність від позацентрово стиснутих елементів та залежність переміщення пружного стержня від величини стискаючої сили.

Дослідженню роботи залізобетонних елементів, що стиснуті поздовжньою силою, в процесі експлуатації сприймають згин від дії поперечного короткочасного динамічного та статичного навантаження, присвячена робота [6]. На основі експериментальних даних робиться висновок, що міцність стиснуто-зігнутих стержнів при поперечному згині статичним або динамічним навантаженням зростає при збільшенні рівня сил обтиснення, а також процента армування. Однак, із збільшенням зусиль поздовжнього обтиснення елементів зменшується іх здатність до непружного деформування, що призводить до крихкого руйнування бетону по всій висоті поперечного перерізу в найбільш напруженому місці. Виконані експерименти дозволили також перевірити і уточнити формулу чинних на той час 


\section{W 1 A N}

норм (СНиП II-21-75 ”Бетонные и железобетонные конструкции“) для визначення усередненої жорсткості стиснуто-зігнутих елементів із урахуванням тріщин у розтягнутій зоні, поздовжньої сили та інших факторів.

Велику групу конструкцій, в нормальних перерізах яких виникають зусилля стиску зі згином, представляють попередньо напружені елементи на стадії виготовлення та монтажу. У цьому випадку поздовжньою силою є зусилля обтиснення. В роботі [7] висвітлено результати дослідів таких елементів, що підтвердили неприйнятність використання коефіцієнта гнучкості елементів $\eta$, визначеного як для позацентрово стиснутих елементів, у розрахунках стиснуто-зігнутих елементів. Автори [7] запропонували формули для визначення коефіцієнта $\eta$, але тільки для випадку, коли діє одна поперечна сила в середині довжини елемента. Отже, врахування гнучкості в розрахунках стиснуто-зігнутих елементів потребує уточнення.

Грунтовні дослідження роботи стиснуто-зігнутих елементів виконані в Національному університеті водного господарства та природокористування [8-10]. Випробувано 24 колони 3 поперечним перерізом $100 \times 160$ мм та довжиною 150 і 300 см. Колони піддавали дії поздовжньої осьової сили та поперечного навантаження за схемою чистого згину. Навантаження прикладали одноразово та повторно. При цьому співвідношення поздовжнього і поперечного навантаження варіювалося. На основі отриманих експериментальних даних i теоретичних досліджень ще до надання чинності документам [3, 4] було підтверджено доцільність використання деформаційної моделі перерізів, оскільки показано, що перед руйнуванням максимальні деформації стиснутого бетону можуть вдвічі перевищувати деформації, визначені при осьовому стисканні бетонних призм. Важливим є і той висновок, що результати визначення напружено-деформованого стану поперечних перерізів стиснуто-зігнутих елементів за деформаційною моделлю у виконаних дослідах не залежали від вибору формули для описання діаграми деформування бетону.

У роботах $[11,12]$ розглянуто форми напруженодеформованого стану нормальних перерізів стиснуто-зігнутих елементів, наведено рівняння їх рівноваги, виходячи 3 розрахункових значень міцності і деформаційних характеристик матеріалів, та подано метод розрахунку несучої здатності елементів. Показано, що теоретичні значення несучої здатності елементів мають задовільну збіжність із експериментальними даними.

Як видно із зазначеного, дослідженням та розробленню методів розрахунку стиснуто-зігнутих елементів за граничними станами другої групи не надавалась належна увага, що стало обгрунтуванням досліджень, висвітлених у цій статті.

\section{УМОВИ РІВНОВАГИ НОРМААЬНИХ ПЕРЕРIЗIB СТИСНУТО-ЗІГНУТИХ ЗАЛІЗОБЕТОННИХ ЕЛЕМЕНТІВ}

У правилах проектування залізобетонних конструкцій [4] відповідно до [3] для елементів прямокутного перерізу при позацентровому стиску i згині розглядаються дві форми рівноваги: весь переріз стиснутий; в перерізі є зона розтягу. Для цих форм напружено-деформованого стану наведено умови рівноваги в розгорнутому вигляді [4]. Оскільки в стиснуто-зігнутих елементах поперечний переріз залежно від співвідношення значень осьової сили і поперечного згинального моменту також може бути повністю стиснутим або частково стиснутим i частково розтягнутим, то і для них можна вважати справедливими форми рівноваги, наведені в [4]. Дві форми рівноваги для стиснуто-зігнутих елементів вже використані при розробленні методу їх розрахунку за несучою здатністю (рис. 2) [11].
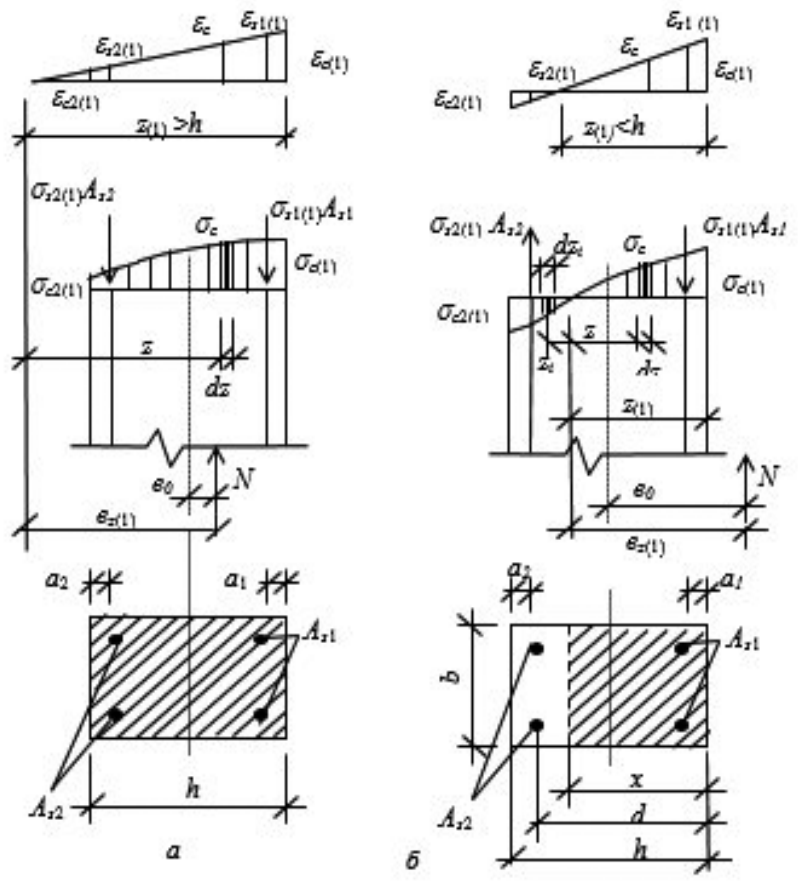

Рис. 2. Перша (а) та друга (б) форми напруженодеформованого стану стиснуто-зігнутих елементів прямокутного перерізу

У розрахунках стиснуто-зігнутих елементів за граничними станами другої групи немає доцільності розглядати їхній напружено-деформований стан за першою формою (рис. 2, а), тому що в цьому випадку виникнення тріщини неможливе, а кривизна елемента несуттєва. Отже, більш докладно розглянемо умови рівноваги стиснуто-зігнутих елементів за другою формою напружено-деформованого стану (рис. 2, б), при цьому в розрахункових формулах необхідно використовувати характеристичні значення міцності та деформативності бетону і арматури.

За умови, що відомі деформація крайньої фібри стиснутого бетону $\varepsilon_{c(l)}$ та відповідна їй величина стиснутої зони бетону $x=z_{(l)}$, використовуючи гіпотезу плос- 
ких перерізів, можна визначити всі інші деформації в матеріалах залежно від значення $\varepsilon_{c(l)}$ та $z_{(I)}$ :

$$
\begin{gathered}
\varepsilon_{s 1(1)}=\frac{\varepsilon_{c(1)}}{z_{(1)}}\left(z_{(1)}-a_{1}\right) ; \varepsilon_{s 2(1)}=\frac{\varepsilon_{c(1)}}{z_{(1)}}\left(h-z_{(1)}-a_{2}\right) ; \\
\varepsilon_{c}=\frac{\varepsilon_{c(1)}}{z_{(1)}} z ; z=\frac{z_{(1)}}{\varepsilon_{c(1)}} \varepsilon_{c} ; d z=\frac{z_{(1)}}{\varepsilon_{c(1)}} d \varepsilon_{c} .
\end{gathered}
$$

Для другої форми рівноваги (рис. 2, б) рівняння суми проекцій поздовжніх сил $\Sigma N=0$ можна записати у такому вигляді:

$$
b \int_{0}^{z_{(1)}} \sigma_{c} d z+\sigma_{s 1(1)} A_{s 1}-\sigma_{s 2(1)} A_{s 2}-N=0,
$$

де $N$ - поздовжня осьова сила від зовнішнього навантаження, що діє 3 ексцентриситетом $e_{0}$ по відношенню до центра ваги перерізу.

Враховуючи співвідношення (1) та приймаючи діаграму деформування бетону у формі поліному п'ятого степеня [1], рівняння (2) можна записати у вигляді

$$
\begin{gathered}
f_{c k} b \frac{z_{(1)}}{\varepsilon_{c(1)}} \int_{0}^{\varepsilon_{c 1(1)}} \sum_{k=1}^{5} a_{k}\left(\frac{\varepsilon_{c}}{\varepsilon_{c 1, c k}}\right)^{k} d \varepsilon_{c}+\frac{\varepsilon_{c(1)}}{z_{(1)}}\left(z_{(1)}-a_{1}\right) E_{s} A_{s 1}- \\
-\frac{\varepsilon_{c(1)}}{z_{(1)}}\left(h-z_{(1)}-a_{2}\right) E_{s} A_{s 2}-N=0,
\end{gathered}
$$

де $f_{c k}$ - характеристичне значення міцності бетону на стиск; $a_{k}-$ коефіцієнти полінома для граничних станів другої групи [1]; $\varepsilon_{c l, c k}-$ деформація бетону при максимальних напруженнях при розрахунках за граничними станами другої групи.

Після інтегрування та відповідних математичних перетворень рівняння (3) може бути представлене так:

$$
\begin{gathered}
f_{c k} b z_{(1)} \sum_{k=1}^{5} \frac{a_{k}}{k+1}\left(\frac{\varepsilon_{c(1)}}{\varepsilon_{c 1, c k}}\right)^{k}+\frac{\varepsilon_{c(1)}}{z_{(1)}}\left(z_{(1)}-a_{1}\right) E_{s} A_{s 1}- \\
-\frac{\varepsilon_{c(1)}}{z_{(1)}}\left(h-z_{(1)}-a_{2}\right) E_{s} A_{s 2}-N=0 .
\end{gathered}
$$

Рівняння (4) має більш удосконалену структуру ніж відповідне рівняння, що наведене в [4], де в першому члені рівняння перед знаком суми міститься відносна кривизна вигнутої осі в перерізі, що ускладнюе розуміння фізичної суті зусилля в стиснутому бетоні. У формулі (4) перед знаком суми міститься вираз, що відповідає зусиллю в стиснутому бетоні за умови рівномірного розподілу в ньому напружень, а під знаком суми коефіцієнт

\begin{tabular}{|c|c|c|c|c|c|c|c|c|c|c|}
\hline \multirow{3}{*}{$\frac{\varepsilon_{c}}{\varepsilon_{c 1, c k}} *$} & \multicolumn{10}{|c|}{ Kлас бетону } \\
\hline & \multicolumn{2}{|c|}{ C16/20 } & \multicolumn{2}{|c|}{$\mathrm{C} 20 / 25$} & \multicolumn{2}{|c|}{$\mathrm{C} 25 / 30$} & \multicolumn{2}{|c|}{ C30/35 } & \multicolumn{2}{|c|}{ C $32 / 40$} \\
\hline & $w_{x}$ & $\beta_{s}$ & $w_{\kappa}$ & $\beta_{\kappa}$ & $w_{n}$ & $\beta_{x}$ & $w_{n}$ & $\beta_{\kappa}$ & $w_{k}$ & $\beta_{n}$ \\
\hline 0,1 & 0,133 & 0,088 & 0,125 & 0,083 & 0,119 & 0,079 & 0,114 & 0,076 & 0,110 & 0,073 \\
\hline 0,2 & 0,247 & 0,162 & 0,235 & 0,154 & 0,225 & 0,148 & 0,217 & 0,143 & 0,210 & 0,139 \\
\hline 0,3 & 0,346 & 0,224 & 0,331 & 0,215 & 0,319 & 0,208 & 0,310 & 0,202 & 0,301 & 0,197 \\
\hline 0,4 & 0,430 & 0,276 & 0,414 & 0,267 & 0,402 & 0,260 & 0,392 & 0,254 & 0,383 & 0,249 \\
\hline 0,5 & 0,503 & 0,320 & 0,486 & 0,311 & 0,474 & 0,304 & 0,464 & 0,299 & 0,456 & 0,294 \\
\hline 0,6 & 0,564 & 0,355 & 0,548 & 0,347 & 0,537 & 0,341 & 0,528 & 0,337 & 0,520 & 0,333 \\
\hline 0,7 & 0,616 & 0,384 & 0,601 & 0,377 & 0,591 & 0,372 & 0,582 & 0,368 & 0,575 & 0,365 \\
\hline 0,8 & 0,660 & 0,407 & 0,646 & 0,401 & 0,637 & 0,397 & 0,629 & 0,394 & 0,623 & 0,392 \\
\hline 0,9 & 0,696 & 0,426 & 0,684 & 0,421 & 0,675 & 0,417 & 0,669 & 0,415 & 0,663 & 0,413 \\
\hline 1,0 & 0,726 & 0,440 & 0,716 & 0,436 & 0,708 & 0,433 & 0,702 & 0,431 & 0,697 & 0,429 \\
\hline 1,1 & 0,751 & 0,450 & 0,741 & 0,447 & 0,734 & 0,444 & 0,729 & 0,443 & 0,724 & 0,442 \\
\hline 1,2 & 0,771 & 0,457 & 0,762 & 0,454 & 0,755 & 0,452 & 0,750 & 0,451 & 0,746 & 0,450 \\
\hline 1,3 & 0,787 & 0,462 & 0,778 & 0,459 & 0,772 & 0,457 & 0,767 & 0,456 & 0,764 & 0,455 \\
\hline 1,4 & 0,799 & 0,464 & 0,790 & 0,461 & 0,784 & 0,459 & 0,780 & 0,458 & 0,776 & 0,457 \\
\hline 1,5 & 0,808 & 0,464 & 0,799 & 0,461 & 0,793 & 0,459 & 0,788 & 0,457 & 0,784 & 0,456 \\
\hline 1,6 & 0,813 & 0,462 & 0,804 & 0,459 & 0,798 & 0,456 & 0,793 & 0,455 & 0,788 粶业 & $0,452^{2}$ * \\
\hline 1,7 & 0,816 & 0,459 & 0,807 & 0,455 & 0,801 & 0,452 & 0,795 & 0,450 & & \\
\hline 1,8 & 0,817 & 0,454 & 0,807 & 0,449 & 0,800 & 0,447 & $0,793^{\text {冰水 }}$ & $0,442^{*}$ * & & \\
\hline 1,9 & 0,816 & 0,448 & 0,805 & 0,443 & $0,798^{\text {* * * * }}$ & $0,439^{\text {tr }}$ & & & & \\
\hline 2,0 & 0,812 & 0,441 & 0,801 & 0,435 & & & & & & \\
\hline 2,1 & 0,807 & 0,432 & 0,795 & 0,426 & & & & & & \\
\hline
\end{tabular}
повноти епюри напружень $\omega_{k}$, що враховує іiі криволінійність і залежить тільки від класу бетону та рівня деформацій, а тому може бути представлений у табличній формі (табл. 1).

Таблиця 1. Значення коефіцієнтів повноти епюри напружень $\left(w_{k}\right)$ і відносної міцності бетону $\left(\beta_{k}\right)$ для розрахунків за граничними станами другої групи

Примітки:

*- $\varepsilon_{c l}, c_{k}-$ деформація бетону при максимальних напруженнях при розрахунках за граничними станами другої групи; $\varepsilon_{c}-$ біжуче значення деформації бетону;

** - при значеннях $\varepsilon_{c u l, c k} / \varepsilon_{c l, c k}$ 


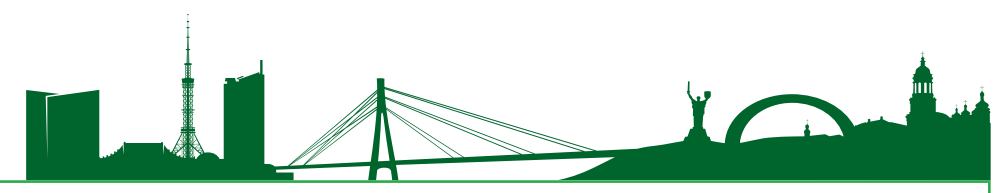

3 урахуванням використання коефіцієнта повноти епюри напружень у стиснутому бетоні перша умова рівноваги набуває такого кінцевого вигляду:

$$
\begin{aligned}
& \omega_{k} f_{c k} b z_{(1)}+\frac{\varepsilon_{c(1)}}{z_{(1)}}\left(z_{(1)}-a_{1}\right) E_{s} A_{s 1}- \\
& \frac{\varepsilon_{c(1)}}{z_{(1)}}\left(h-z_{(1)}-a_{2}\right) E_{s} A_{s 2}-N=0 .
\end{aligned}
$$

Аналогічно можна отримати рівняння рівноваги стосовно діючих в перерізі згинаючих моментів, що після інтегрування і математичних перетворень вихідного рівняння набуває вигляду:

$$
\begin{gathered}
f_{c k} b z_{(1)}^{2} \sum_{k=1}^{5} \frac{a_{k}}{k+2}\left(\frac{\varepsilon_{c(1)}}{\varepsilon_{c 1, c k}}\right)^{k}+\frac{\varepsilon_{c(1)}}{z_{(1)}}\left(z_{(1)}-a_{1}\right)^{2} E_{s} A_{s 1}+ \\
+\frac{\varepsilon_{c(1)}}{z_{(1)}}\left(h-z_{(1)}-a_{2}\right)^{2} E_{s} A_{s 2}-N\left(z_{(1)}-0,5 h+e_{0}\right)=0,
\end{gathered}
$$

де $e_{0}-$ ексцентриситет прикладання поздовжньої сили $e_{0}=M / N$.

У рівнянні (6) в першому члені під знаком суми міститься коефіцієнт $\beta_{k}$, що враховує криволінійну епюру напружень у стиснутому бетоні при визначенні величини згинального моменту. Цей коефіцієнт, як і коефіцієнт $w_{k}$, залежить від класу бетону та рівня деформацій стиснутої крайньої зони бетону і також може бути представленим у табличній формі (табл. 1). 3 урахуванням цього рівняння рівноваги (6) може бути записаним у вигляді

$$
\begin{gathered}
\beta_{k} f_{c k} b z_{(1)}^{2}+\frac{\varepsilon_{c(1)}}{z_{(1)}}\left(z_{(1)}-a_{1}\right)^{2} E_{s} A_{s 1}+ \\
\frac{\varepsilon_{c(1)}}{z_{(1)}}\left(h-z_{(1)}-a_{2}\right)^{2} E_{s} A_{s 2}-N\left(z_{(1)}-0,5 h+e_{0}\right)=0 .
\end{gathered}
$$

Форма запису рівнянь (5) і (7) дещо відрізняється від форми запису аналогічних рівнянь, наведених в [4], а саме, вони не містять у собі відносної кривизни елементів, у них введено коефіцієнти $w_{k}$ і $\beta_{k}$, що дозволяє спростити процес розрахунку напружено-деформованого стану нормальних перерізів стиснуто-зігнутих елементів, використовуючи метод поступового наближення [4].

\section{ВИЗНАЧЕННЯ НАПРУЖЕНО-ДЕФОРМО- ВАНОГО СТАНУ НОРМААЬНИХ ПЕРЕРІЗІВ СТИСНУТО-ЗІГНУТИХ ЕЛЕМЕНТІВ ПРИ ЕКСПЛУАТАЦІЙНИХ НАВАНТАЖЕННЯХ}

Для розрахунків елементів за граничними станами другої групи необхідно визначити деформації в матеріалах при дії експлуатаційного навантаження, для чого виконується аналіз зміни напруженодеформованого стану нормальних перерізів шляхом спільного рішення рівнянь (5) і (7) за умови приросту деформацій, внаслідок чого встановлюється зв'язок “стискальна сила - деформація” (“N $-\varepsilon_{c}$ ”).
Цей зв'язок може бути представлений у табличній формі або у вигляді відповідної діаграми. Задача вирішується методом послідовних наближень [4]. При цьому вважаються відомими всі геометричні характеристики поперечного перерізу елемента, параметри діаграм деформування матеріалів та ексцентриситет прикладання поздовжньої сили $e_{0}$.

У рівняннях рівноваги поперечного перерізу (5) i (7) при заданому значенні деформації бетону $\varepsilon_{c(1)}$ невідомою є висота стиснутої зони бетону $x$. Практично задача знаходження невідомого вирішується методом наближень із заданою точністю $\mathrm{m}$, яку можна встановити $2 \%$ або $5 \%$. На першому кроці наближення при $\varepsilon_{c}=\varepsilon_{c(I)}$ можна прийняти $x=z_{(l)}=0,5 d i$, використовуючи формулу (5), визначити відповідну поздовжню силу

$$
\begin{aligned}
& N_{(1)}=\omega_{k} f_{c k} b z_{(1)}+\frac{\varepsilon_{c(1)}}{z_{(1)}}\left(z_{(1)}-a_{1}\right) \\
& E_{s} A_{s 1}-\frac{\varepsilon_{c(1)}}{z_{(1)}}\left(h-z_{(1)}-a_{2}\right) E_{s} A_{s 2} .
\end{aligned}
$$

За знайденим значенням $N_{(1)}$ перевіряється виконання рівняння рівноваги (7) за виразом

$$
\frac{\beta_{k} f_{c k} b z_{(1)}^{2}+\frac{\varepsilon_{c(1)}}{z_{(1)}}\left(z_{(1)}-a_{1}\right)^{2} E_{s} A_{s 1}+\frac{\varepsilon_{c(1)}}{z_{(1)}}\left(h-z_{(1)}-a_{1}\right)^{2} E_{s} A_{s 2}}{N_{(1)}\left(z_{(1)}-0,5 h+e_{0}\right)}=(1 \pm m) .(9)
$$

У формулах (8) і (9) коефіцієнти $w_{k}$ і $\beta_{k}$ приймають за табл. 1 при фактичному значенні відношення $\varepsilon_{c(1)} / \varepsilon_{c l, c \kappa}$.

Якщо умова (9) виконується, то це свідчить про те, що вже на першому кроці знайдено рішення системи рівнянь (5) і (6) і можна знайти величину згинального моменту $M_{(1)}$ та кривизну елемента $\chi_{(1)}$, що відповідають значенням $\varepsilon_{c(1)}$ і $N_{(1)}$, за такими формулами:

$$
\begin{gathered}
M_{(1)}=N_{(1)}\left(z_{(1)}-0,5 h+e_{0}\right) ; \\
\chi_{(1)}=\frac{\varepsilon_{c(1)}+\varepsilon_{s 2(1)}}{d}
\end{gathered}
$$

де $\varepsilon_{s 2(1)}-$ відносна деформація розтягнутої арматури, що визначається за формулою $(1) ; d$ - робоча висота поперечного перерізу (рис. 2, б).

Якщо умова (9) не дотримується, необхідно виконати другий крок наближення, в якому при тому ж значенні $\varepsilon_{c(1)}$ необхідно змінити величину стиснутої зони бетону, прийнявши іiї $z_{(2)}=z_{(1)}(1 \pm i)$, де $i-$ крок наближення (можна приймати $i=0,02$ або 0,05). При значенні $x=z_{(2)}$ виконуються всі розрахунки i перевіряється умова (9). Якщо і на цьому кроці вона не виконується, робиться третій крок наближення, приймаючи $z_{(3)}=z_{(2)}(1 \pm i)$. Такі наближення виконують до досягнення умови (9). За визначеним в останньому наближенні $z_{(\text {n) }}(n-$ номер кроку остан- 
нього наближення) за формулами (10) і (11) визначають значення згинаючого моменту $M_{(n)}$ та $\chi_{(n)}$, що відповідають значенням $\varepsilon_{c(1)}$ і $N_{(n)}$.

У результаті виконаних за наведеним методом розрахунків отримано параметри діаграми механічного стану перерізу в першій іiі точці, а саме, при значенні деформації бетону більш стиснутої грані, рівній $\varepsilon_{c(1)}$. Для отримання наступних точок діаграми стану перерізу необхідно виконати розрахунки при інших значеннях деформацій $\varepsilon_{c}$ в межах від 0 до $\varepsilon_{c u l, c k}$. Як правило, 3 достатньою точністю отримують результати при зміні деформацій через $\Delta \varepsilon_{c(1)}=0,1 \varepsilon_{c 1, c k}$. Тобто, $\varepsilon_{c(1)}=0,1 \varepsilon_{c 1, c k} ; \varepsilon_{c(2)}=0,2 \varepsilon_{c 1, c k} ;$ $\varepsilon_{c(10)}=\varepsilon_{c 1, c k}$ і так далі до $\varepsilon_{c u l, c k}$.

Для подальшого аналізу отримані характеристики напружено-деформованого стану перерізу залежно від $\varepsilon_{c}$ зводяться в таблицю або за їх даними будують необхідні діаграми.

Всі розрахунки легко і з мінімальною затратою часу виконуються в програмі Excel.

\section{РОЗРАХУНОК РОЗКРИТТ ЯМ ДЕФОРМАЦЯМИ}

\section{EЛЕMEHTIB ТРІЩИН ТА}

У розрахунках залізобетонних конструкцій за придатністю до нормальної експлуатації розглядається напружено-деформований стан перерізу при дії навантажень із характеристичними значеннями. Стосовно стиснуто-зігнутих елементів від таких навантажень визначають осьову силу $N_{S L S}$ від поздовжнього навантаження та максимальний згинаючий момент $M_{S L S}$ від поперечного навантаження. Спільну дію осьової сили і згинаючого моменту в розрахунках можна замінити дією сили $N_{S L S} 3$ ексцентриситетом $e_{0}=M_{S L S} / N_{S L S}$. За наведеним вище методом будується діаграма механічного стану поперечного перерізу (можливо в табличній формі), за якою визначають значення параметрів напружено-деформованого стану при $N=N_{S L S}$.

Ширину розкриття тріщин $w_{k}$ у нормальному перерізі елемента визначають за формулою [4]

$$
w_{k}=s_{r, \max }\left(\varepsilon_{s m}-\varepsilon_{c t m}\right)
$$

де $-\varepsilon_{s m}-\varepsilon_{c t m}$ різниця між середніми деформаціями в арматурі та середніми деформаціями бетону між тріщинами, що знаходять за формулою

$$
\left(\varepsilon_{s m}-\varepsilon_{c t m}\right)=\frac{\sigma_{s}-k_{t}\left(1+a_{e} \rho_{p, e l f}\right) \frac{f_{c t, e l f}}{\rho_{p, e l f}}\left(1+a_{e} \rho_{p, e l f}\right)}{E_{s}} \geq 0,6 \frac{\sigma_{s}}{E_{s}}
$$

У формулі (13) напруження в розтягнутій арматурі в перерізі з тріщиною $\sigma_{s}$ знаходять за діаграмою механічного стану при $N=N_{S L S}$. Усі інші величини, що містяться в формулах (12) і (13), та їх визначення наведені в [4]. Аналогічно може бути визначена ширина розкриття тріщин від дії довготривалих навантажень.
Також із використанням розрахованої діаграми стану поперечного перерізу визначають кривизну елемента $x$ при $N=N_{S L S}$, за значенням якої знаходиться прогин елемента $f$ за відомою формулою, в якій позначення прийняті відповідно до [4],

$$
f=k_{m} \chi l^{2} \text {. }
$$

Отже, із зазначеного випливає, що для розрахунку стиснуто-зігнутих елементів за граничними станами другої групи необхідно встановлювати діаграму зміни напружено-деформованого стану поперечного перерізу залежно від рівня навантаження (рівня деформації бетону), що дає можливість встановлювати напруження в матеріалах, їх деформації та кривизну при дії експлуатаційного навантаження. Крім цього, розраховані діаграми механічного стану за наведеним методом дають можливість визначити руйнівне навантаження, що дорівнює $N_{u}=N_{\max }$ при $d_{N} / d \varepsilon_{c}=0$.

\section{ВИСНОВКИ}

1. Отримано математично удосконалені умови рівноваги нормальних перерізів стиснутозігнутих залізобетонних елементів, що відповідають сучасній деформаційній моделі їх роботи.

2. Спільне рішення рівнянь рівноваги дає можливість отримати зміну напруженодеформованого стану нормальних перерізів елементів при різних рівнях навантаження та визначити напруження і деформації в матеріалах при їх характеристичних значеннях, що необхідні для розрахунку елементів за граничними станами другої групи.

3. Запропонований метод легко реалізується в програмі Excel, що забезпечує використання в повному обсязі деформаційної моделі при проектуванні залізобетонних конструкцій.

\section{БІБАІОГРАФІЧНИЙ СПИСОК}

1. Бамбура А.М. Основні положення розрахунку бетонних та залізобетонних конструкцій по національному нормативному документу (ДБН), що розробляється / А.М. Бамбура, А.Я. Барашиков, О.Б. Гурківський // Буд. конструкції: 3б. наукових пр. - Київ: НДІБК, 2005. - Том 1. - С. $36-43$.

2. Бамбура А.М. Нове в проектуванні залізобетонних та сталезалізобетонних конструкцій / А.М. Бамбура, О.Б. Гурківський, М.С. Безбожна, О.В. Дорогова, I.P. Сазонова // Буд. конструкції: 36. наукових пр. - Київ: НДІБК, 2013. Вип. 78. - Кн. 1.- С. 3 - 13.

3. Бетонні та залізобетонні конструкції: ДБН В.2.6 - 98:2009. - [Чинні від 2011-07-01]. - Київ: ДП “Укрархбудінформ”, 2011. - 84 с. (Буд. норми України). 


\section{MINAM}

4. Бетонні та залізобетонні конструкції з важкого бетону: ДСТУ Б В.2.6 - 156:2010. - [Чинний від 2011 - 06 - 01]. - Київ: ДП “Укрархбудінформ”, 2011. - 118 с. -(Національний стандарт України).

5. Справочник проектировщика промышленных, жилых и общественных зданий и сооружений. Расчетно-теоретический. Кн. 2 / Под ред. А.А. Уманского. - М.: Стройиздат, 1973. - 416 с.

6. Пузанков Ю.И. Прочность и деформативность сжатых железобетонных элементов при поперечной динамической нагрузке: автореф. дисс. канд. тех. наук: 05.23.01 / Ю.И. Пузанков.- М., 1979.- 22 c.

7. Казачек В.Г. Исследование гибких сжатоизогнутых предварительно напряженных железобетонных колонн / В.Г Казачек // Вопросы строительства и архитектуры. - Минск: Вышэйшая школа, 1979. Вып. 9. - С. 99-106.

8. Бабич E.E. Робота стиснуто-зігнутих залізобетонних елементів при одноразових та повторних малоциклових навантаженнях / E.E. Бабіч, О.О. Заречанський // Буд. конструкції: 3б. наукових пр. - Київ: НДІБК, 2005. - Кн. 1.- С. $17-23$.

9. Бабич E.M. Експериментальні дослідження гнучких стиснуто-зігнутих залізобетонних елементів при поперечних повторних навантаженнях різних рівнів / E.М. Бабич, О.О. Заречанський // Буд. конструкції: 3б. наукових пр. - Київ: НДІБК, 2006. - Вип. 65. С. $253-259$.

10. Заречанський О.О. Особливості роботи гнучких стиснуто-зігнутих залізобетонних елементів при повторній дії поздовжньої сили / О.О. Заречанський // Ресурсоекономні матеріали, конструкції, будівлі та споруди: 36. наукових пр. - Рівне: НУВГП, 2006. - Вип. 14. - C. 187 - 194.

11. Бабіч E.C. Практичний метод визначення напружено-деформованого стану і міцності стиснуто-зігнутих залізобетонних елементів 3 використанням деформаційної моделі / Є.С. Бабіч // Буд. конструкції: 3б. наукових пр.- Київ: ДП НДІБК, 2007.- С. 68 - 77.

12. Бабіч E.E. Розрахунок несучої здатності стиснуто-зігнутих залізобетонних елементів /E.Є. Бабіч, Є.М. Бабич // Буд. конструкції: 36. наукових пр. - Київ: ДП НДІБК, 2013. - Вип. 78. - Кн. 1.- С. 158 - 164.

\section{REFERENCES}

1. Bambura, A.M., Barashykov, A. Ia., \& Hurkivskyi, O. B. (2005). Basic provisions for the calculation of concrete and reinforced concrete structures under the national normative document (DBN) being developed. Building constructions: Collection of scientific papers, 1, $36-43$.
2. Bambura, A.M., Hurkivskyi, O. B., Bezbozhna, M. S., Dorohova, O. V., \& Sazonova I. R. (2013). New in the design of reinforced concrete and steel reinforced concrete structures. Building constructions: Collection of scientific papers, 78(1), $3-13$.

3. Concrete and reinforced concrete structures: DBN V.2.6-98:2009. (2010). Kyiv: DP

"Ukrarkhbudinform".

4. Concrete and reinforced concrete constructions made of heavy concrete: DSTU B V.2.6 - 156: 2010. (2011). Kyiv: DP "Ukrarkhbudinform".

5. Umanskoi, A.A. (Ed). (1973). Directory of designer of industrial, residential and public buildings and structures. Settlement-theoretical. (Book 2). Moscow: Stroiizdat.

6. Puzankov, Yu. I. (1979). Strength and deformability of compressed reinforced concrete elements with transverse dynamic load. (Candidate's thesis abstract). Moscow.

7. Kazachek, V.H. (1979). Investigation of flexible compressed-curved pre-stressed reinforced concrete columns. Questions of construction and architecture, 9, 99-106.

8. Babich, Ie.Ie., \& Zarechanskyi, O. (2005). The work of compressed-bent concrete elements with onetime and repeated small-cycle loads. Building Constructions: Collection of scientific papers, 1, 17 - 23.

9. Babych, Ye.M., \& Zarechanskyi, O.O. (2006). Experimental studies of flexible compressed-bent concrete elements at transverse repeated loads of different levels. Building constructions: Collection of scientific papers, 65, 253 - 259.

10. Zarechanskyi, O.O. (2006). Peculiarities of the work of flexible compressed-bent curtain reinforced concrete elements with repeated action of longitudinal force. Resource-saving materials, structures, buildings and structures: Collection of scientific papers, 14, 187 - 194.

11. Babich, Ie.Ie. (2007). Practical method for determining the stress-strain state and strength of compressed-bent concrete elements using a deformation model. Building Constructions: Collection of scientific papers, 68 - 77.

12. Babich, Ie. Ie., Babych, Ie. M. (2013). Calculation of the bearing capacity of compressed-bent concrete elements. Building Constructions: Collection of scientific papers, 78(1), 158 - 164.

Стаття надійшла до редакції 14.08.2017 р. 